\section{Radice labels the city technology colleges "a miserable flop"}

\section{London}

THE British government - still on its way to a comfortable election win according to the opinion polls - is trying to boost its innovative experiment on industry-funded secondary schools, in the face of continued opposition from the Labour Party and local authorities. A special charitable trust has been set up to push the establishment of what the government is calling "city technology colleges", paid for by industry and geared towards science and technology.

The new colleges would be owned and run by industry, outside local authority control, and each would cater for up to a thousand 11- to 18-year-olds in inner city areas. Sponsoring companies would use their own staff as teachers, and would develop a curriculum to meet their own needs. According to Mr Kenneth Baker, Secretary of State for Education, at least 25 per cent of teaching time would be devoted to science and technology.

Baker hopes to set up 20 city technology colleges by the end of the decade, if he can get industry to respond. So far, the government has approached nearly 4,000 companies, and three have agreed to sponsor new secondary schools to the tune of $£ 1$ million: the Anglo-US conglomerate Hanson Trust at Solihull in the West Midlands; Dixons Group, operator of a national chain of retail electrical goods stores, in South Yorkshire; and Sir Philip Harris, chairman of the Harris/Queensway furniture group, at Wandsworth in London.

Of the three, only the Solihull proposal has a definite site. In other areas, the education authorities have not been keen to turn over their property. But the government has now indicated that it will use legislation to force local authorities to make land or buildings available.

A search for sites and for more sponsors is being led by the City Technology Colleges Trust, a group of educationalists and industralists. But the Labour Party is pledged to refuse to support the new schools if it becomes the government after the 11 June election. Labour's education spokesman, Giles Radice, calls industry's response "abysmal", and adds, "the city technology colleges look set to be a miserable flop".

Labour does not like the idea of a lack of local authority control over the technology colleges, and it is also against the selective admission policies that would be applied. The Labour-controlled Association of Metropolitan Authorities has also come out in opposition.

Teachers' unions are resisting the new institutions. The recent conference of the
National Union of Teachers voted to organize a consumer boycott of sponsoring companies such as Dixons. The teachers fear that industry-funded colleges would cream off science and mathematics teachers and motivated students from state schools.

But some businesses are sceptical, and do not see why industry should fund schools at such a high level. The reward for companies, according to the government's glossy promotional brochure, will be "richer opportunities for good education in the cities and an enhanced contribution to the vigour and prospects of the communities there". However, three of Britain's largest companies, IBM, ICI, and $\mathrm{BP}$, still remain unconvinced and have declined to provide backing for the new colleges.

The idea of better science education is laudable, says Professor Denis Noble of the Save British Science organization. "But an improvement is needed for at least 1,000 schools, not just 20 ". The danger, he adds, "is that this programme may make us complacent and divert attention from the larger problem. It's a typical English solution to massive education problems: improve some schools at the top of the system and forget about the rest."

Kathy Johnston

\section{Britain seeks to share telescope costs}

\section{London}

BRITISH astronomers are seeking to share the $£ 350,000$ annual cost of their UK Schmidt telescope with Australia. The time for Britons, is aimed at "value for money", says Dr John Litt of the Science and Engineering Research Council.

"International collaboration can help us by sharing the costs and bringing in another country's resources and expertise", Litt says. The council last month sold a share in its new James Clerk Maxwell telescope in Hawaii to Canadian astronomers as part of its economy drive.

The UK Schmidt telescope has been operating at Siding Spring Mountain in South Australia since it was built by the Royal Observatory Edinburgh in 1973. A wide-angle optics telescope, it is often used in conjunction with the nearby AngloAustralian Telescope which operates under an intergovernmental agreement. The equipment is used in quasar discovery work, and its observations identified the progenitor star in the spectacular supernova explosion earlier this year.

Both the British and the Australian governments would have to agree on the cost-sharing move, but with each country facing an election there could be some delays. "This is hardly a high priority election issue", Litt notes. Kathy Johnston proposal, which would halve the viewing

\section{Somebody missing from Nobel line up?}

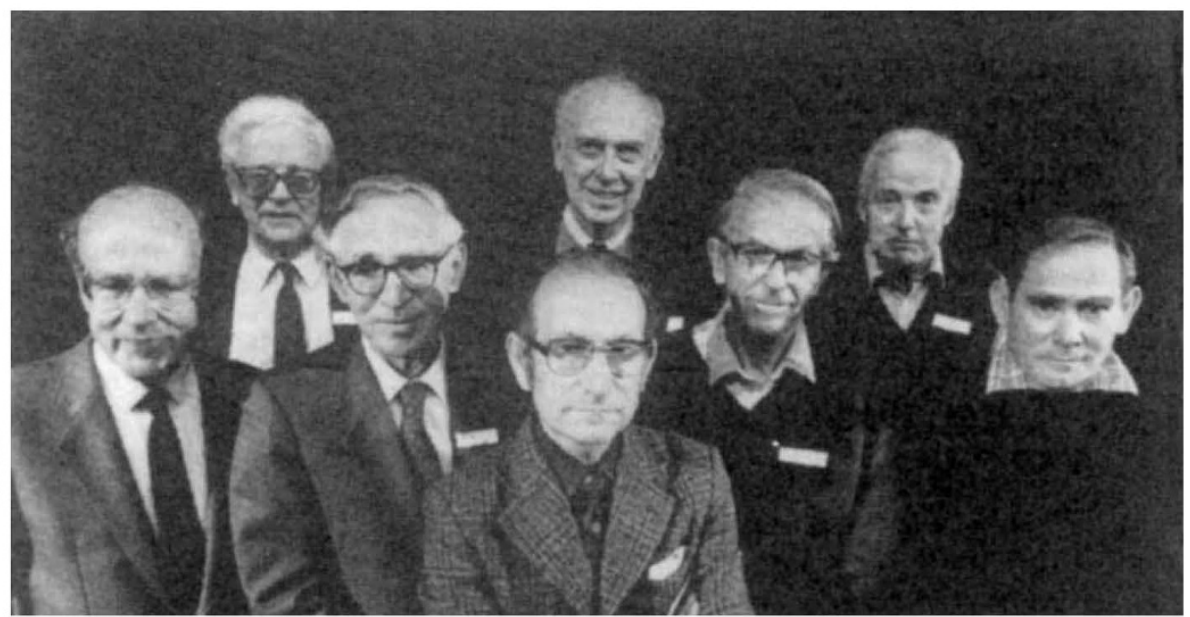

From the left, Max Perutz, John Kendrew, Aaron Klug, James Watson, César Milstein, Fred Sanger, Hugh Huxley and Sydney Brenner pose at the 40th anniversary of the UK Medical Research Council's first foray into molecular biology. All carried out pioneering work in the council's Unit for Research on the Molecular Structure of Biological Systems, founded in 1947 at the Cavendish Laboratory in Cambridge, or in its successor, the Laboratory for Molecular Biology which was opened in 1962. Absent from the group is Francis Crick. It was Watson and Crick who, in 1953, became the first members of the group to win Nobel Prizes. They were followed by Perutz and Kendrew in 1962, Sanger in 1980 (adding to his 1958 Nobel prize for work carried out before he joined the Medical Research Council), Milstein (and Georges Köhler) in 1984 and Klug in 1985. The laboratory remains a centre of excellence for molecular biology but the days when it was unrivalled are long since past. History cannot be repeated, but the question for Aaron Klug, who took over from Sydney Brenner as director of laboratory last year, is how to maintain even its current standing in the face of the relative decline of $U K$ science. 